Springer Link

- Original Paper

- Published: 18 July 2019

\title{
Effect of Silicon Inclusion Carbonaceous Composite Particulate on the Thermal-Ageing Characteristics and Mechanical Performance of Low Carbon Steel
}

- T. O. Joshua,

- O.S. I. Fayomi,

- E. O. Seriki \&

- A. A. Ayoola

Silicon volume 12, pages1231-1236(2020)Cite this article

- 34 Accesses

- Metricsdetails

\section{Abstract}

This study focus on the effects of silicon inclusion carbonaceous particulate on the hardness and microstructural properties of carburized low carbon steel, at constant temperature of $900{ }^{\circ} \mathrm{C}$ with different holding time from 2 to $5 \mathrm{~h}$. The cow bone and coal dust composite particles were varied with $20 \% \mathrm{CaCO}_{3}$ used as the energizer. Hardness and microstructural testing of the various specimens were then carried out using Vickers hardness machine and metallurgical scanning electron microscope. From the result, it was noticed that there was an increase in microhardness performance on both cow bone and coal dust reinforced matrix compared to the as-received samples. For coal dust carburized carbon steel, the hardness value improved from $286 \mathrm{HVN}$ control samples $434.55 \mathrm{HVN}$ in $5 \mathrm{~h}$. It was seen that the introduction of cow bone composite particulate also provides a reasonable mechanical hardness improvement to $418.2 \mathrm{HVN}$ although a little short fall against the coal dust 
metal matrix. From the microstructure and macrostructure studies highly pearlitic matrix steel was observed with grain refinement of $C B$ and $C D$ found at the interface providing an effective nucleation site along the boundaries.

This is a preview of subscription content, access via your institution.

\section{Access options}

Buy single article

Instant access to the full article PDF.

$$
34,95 €
$$

Tax calculation will be finalised during checkout.

$$
\text { Buy article PDF }
$$

\section{Subscribe to journal}

Immediate online access to all issues from 2019. Subscription will auto renew annually.

processing. Silicon 10:343-347. https://doi.org/10.1007/S12633-016$\underline{9451-7}$

\section{Article Google Scholar}

Download references

\section{Author information}

Affiliations

1. Department of Metallurgical and Materials Engineering, Kogi State Polytechnic, Itakpe-, Lokoja, Nigeria

T. O. Joshua

2. Department of Mechanical Engineering, Covenant University, Ota, Ogun State, Nigeria

O. S. I. Fayomi

3. Department of Chemical, Metallurgical and Materials Engineering, Tshwane University of Technology, P.M.B. X680, Pretoria, South Africa

O. S. I. Fayomi 
4. Department of Mechanical Engineering, Kogi State Polytechnic, Itakpe-, Lokoja, Nigeria

E. O. Seriki

5. Department of Chemical Engineering, Covenant University, Ota, Ogun State, Nigeria

A. A. Ayoola

Corresponding author

Correspondence to $\underline{\text { O. S. I. Fayomi. }}$

\section{Additional information}

Publisher's Note

Springer Nature remains neutral with regard to jurisdictional claims in published maps and institutional affiliations.

\section{Rights and permissions}

Reprints and Permissions

\section{About this article}

Cite this article

Joshua, T.O., Fayomi, O.S.I., Seriki, E.O. et al. Effect of Silicon Inclusion

Carbonaceous Composite Particulate on the Thermal-Ageing Characteristics

and Mechanical Performance of Low Carbon Steel. Silicon 12, 1231-1236

(2020). https://doi.org/10.1007/s12633-019-00221-6

Download citation

- Received02 March 2019

- Accepted01 July 2019

- Published18 July 2019

- Issue DateMay 2020

- DOlhttps://doi.org/10.1007/s12633-019-00221-6

Keywords 
Springer Nature

(C) 2021 Springer Nature Switzerland AG. Part of Springer Nature.

Your privacy 